\title{
WORLD GOVERNANCE INDICATORS AND FRAUD: EVIDENCE FROM ONE BELT ONE ROAD COUNTRIES
}

\author{
DNTWI, Stephen \\ Kwadwo ${ }^{1+}$ \\ KONG, Yusheng ${ }^{2}$ \\ MUSAH, \\ Mohammed $^{s}$ \\ DONKOR, Mary ${ }^{4}$
}

\author{
'Faculty of Business Studies, Tamale Technical University, Tamale, Ghana. \\ Email:skantwi@tatu.edu.gh Tel:+233-541-119119 \\ ${ }^{2,3,4}$ School of Finance and Economics, Jiangsu University, Zhenjiang, P.R. \\ China. \\ 'Email:5103181210@stmail.ujs.edu.cn Tel +86-157-51010091 \\ 'Email:prophe2013@yahoo.com Teli +233-243-553618 \\ 'Email:mdonkor34@gmail.com Tel. +86-186-05243659 \\ ABSTRACT
}

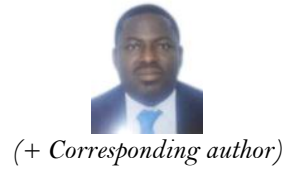

\section{Article History}

Received: 12 February 2021 Revised: 17 March 2021

Accepted: 15 April 2021

Published: 10 May 2021

\section{Keywords}

Fraud

Governance indicators

Global competitiveness

OBOR countries

China.

JEL Classification:

C38; M41; M42; M48; M49.

\begin{abstract}
This paper investigates the effect of worldwide governance indicators and global competitiveness on the level of accounting fraud in One Belt One Road (OBOR) countries. We use publicly available data from various sources. We perform principal components analysis to reduce the six governance indicators to three governance indexes. Governance indicators have significant impact on fraud and the effect could be positive or negative depending on the dimensions involved. Voice and accountability and political stability show significant negative impact on the number of fraud cases. Competitiveness shows a positive but insignificant effect on the level of fraud cases. Democratic countries report lesser number of fraud cases. The findings should be read with caution because of the diversity in the countries in the sample. OBOR countries exhibit different governance models, which may affect their indicators and as a result, the extent of fraud cases reported may be influenced by the regime practiced by a country. The study considers the relevance of governance indicators to policymakers in dealing with rising level of fraud since fraudulent activities affect productivity. Fraud analysis should be embedded in the governance architecture of countries to stimulate development and mitigate the risks of bankruptcies, business failures and loss of investments.
\end{abstract}

Contribution/Originality: The paper contributes to literature on fraud and forensic accounting theories by employing the institutional framework to highlight the occurrence of fraud in different settings.

\section{INTRODUCTION}

In recent times, forensic accounting, which focuses on fraud examination, investigation of bribery and corruption, business valuation, expert witness, cybercrime management/cyber security and litigation support (Crumbley, Heitger, \& Smith, 2015) has emerged as a multi-faceted area. Concerns about the increasing rate of frauds the world over has led to a rise in the demand for forensic accounting (Rezaee \& Wang, 2018). According to the 2018 Global Survey on occupational fraud and abuse, Report to the Nations issued by the Association of Certified Fraud Examiners (ACFE), organizations lose around 5 percent of their total revenues to fraud each year. Applied to the 2017 estimated Gross World Product of USD 79.6 trillion, organizations suffer global fraud loss close to the tune of USD4 trillion (ACFE, 2018). "Fraud is a human endeavor, involving deception, purposeful intent, intensity of desire, risk of apprehension, violation of trust, rationalization” (Ramamoorti \& Olson, 2007). This study examines the influence of governance infrastructure and global competitiveness on accounting fraud. 
This study draws a sample of 65 economies that make up the One Belt One Road (OBOR) countries under the Belt and Roads Initiative (BRI) of China.

Over the years, prior empirical work has focused on understanding the reasons why perpetrators commit fraud, from fraud triangle (Cressey, 1950; Cressey, 1953) to fraud diamond (Wolfe \& Hermanson, 2004) and their further enhancements (Albrecht \& Albrecht, 2009; Cieslewicz, 2010; Kranacher, Riley, \& Wells, 2011; Ramamoorti, Morrison, \& Koletar, 2009). Nevertheless, not much attention has been devoted to fraud cases of international dimension in an attempt to study possible country-wide factors that influence their occurrence. Cieslewicz (2012) evaluates fraud from an international perspective and emphasizes the inclusion of societal-level influences. The author reiterates the global nature of fraud and submits that fraud must be explained from the perspectives of international societies considering philosophical, traditional, cultural and socio-economic dimensions of countries. This study attempts to explain fraud using two critical international factors - world governance and global competitiveness of countries. Good governance is recognized as an objective of development and thus, the power of governance indicators in explaining fraud should be an essential contributor to the discourse of international fraud.

Rutherford (2001) presents the new institutional economics as effort to incorporate social and legal norms into economics. North (1990); North (1994) contends that effective institutions matter for social and economic development. While the quality, credibility and predictability of institutions are essential in providing a stable environment for businesses to thrive with integrity (Siyakiya, 2017) prior literature has not done much to link institutional quality to corporate fraud. Institutional quality influences economic trajectory of countries (Farole, Rodríguez-Pose, \& Storper, 2011). Thus, the complementary role that governance infrastructure can play in international fraud detection and prevention, cannot be overemphasized. Sadaf, Oláh, Popp, and Máté (2018) depict a relationship between the number of fraud cases and institutional determinants for countries that reported fraud cases in 2014 and 2016, according to the Association for Certified Fraud Examiners (ACFE). Máté, Sadaf, Oláh, Popp, and Szücs (2019) also investigate the effects of accountability, governance capital and legal origin on reported frauds using ACFE's datasets for 2014 and 2016. Sadaf et al. (2018) as well as Máté et al. (2019) employ fraud dataset of only two years - 2014 and 2016. This study analyzes the influence of governance and global competitiveness of selected countries on accounting fraud for five years using the available data.

In 2016, China officially outdoored the One Belt and One Road Initiative (OBORI) action plan with 65 countries (as shown in Appendices 1 and 2) from Europe, Middle East and North Africa (MENA), East Asia, Southeast Asia, Central Asia and South Asia (Hafeez, Chunhui, Strohmaier, Ahmed, \& Jie, 2018). While China’s BRI seeks to improve global cooperation in 65 countries (Chin \& He, 2016) it has become imperative to investigate international fraud cases from global institutional perspective. This study, thus, attempts to fill the gap and addresses the following key questions. (1) Do worldwide governance indicators impact on the level of accounting fraud in OBOR countries? (2) What is the effect of global competitiveness on the accounting fraud occurrences in OBOR countries? (3) Does governance type affect the level of accounting fraud in OBOR countries?

This study contributes to the literature in three ways. First, it adds to fraud and forensic accounting literature by critiquing existing fraud theories and providing suggestions to incorporate the multi-dimensionality perspective of fraud. Second, this paper provides explanation to accounting fraud as determined by the governance architecture and competitiveness of countries, and emphasizes the place of good governance in development literature. Last but not the least, this study presents the first effort to model the relationship between the level of accounting fraud occurrence and governance indicators among OBOR countries since the inception of the BRI. This rare study will prompt researchers interested in evaluating the BRI to scrutinize the potential impact of the element of fraud, which has corruption as its form. The rest of the paper proceeds as follows. Section 2 reviews theoretical and empirical literature related to fraud and institutional economics, and also develops hypotheses for the study. Section 3 describes data and methodology that underpin the conduct of the study; the empirical model that seeks to depict relationship between the variables is also specified here. In section 4 , we present empirical results and discuss the 
findings of the study and how those findings relate to prior literature. The last section concludes the entire study, outlines policy implications and makes suggestions for further consideration.

\section{LITERATURE REVIEW}

\subsection{Theoretical Perspectives}

This study is inspired by two fundamental theories - the fraud diamond theory and institutional theory. Theoretical underpinnings of fraud date back to the 1940s and 1950s, and are grounded in the early work of Sutherland (1938) and the seminal work of his student, Cressey (1950); Cressey (1953). The fraud triangle theory was first proposed by Cressey (1953). The attempt to understand the reasons why trusted people violated trust and committed fraud led Cressey (1953)to examine 250 convicted criminals over a period of five months. He analyzed their behaviours on the basis of two criteria: those who were entrusted in good faith with responsibilities and the circumstances that caused them to violate such trust (Abdullahi \& Mansor, 2015a). He came to the conclusion that three key elements - pressure (incentive), opportunity and rationalization - are present in every situation of fraud (Manurung \& Hadian, 2013). It theorizes that the presence of an incentive and perceived opportunity with a given room for rationalization of the fraud as not being inconsistent with one's values, will motivate the person to commit fraud. The works of Sutherland (1938) and Cressey (1950); Cressey (1953) have been expanded and improved as found with the fraud triangle, which was enhanced by Wolfe and Hermanson (2004) with an additional variable and many others. Building on the work of Cressey (1953); Wolfe and Hermanson (2004) added a fourth variable capability - to the fraud triangle theory and came out with the fraud diamond theory. Wolfe and Hermanson (2004) thus, suggest that opportunity exposes the door to fraud, incentive and rationalization point at the opportunity, but capability enables the person to recognize all that and to take advantage of it repeatedly.

The validity and soundness of the fraud triangle and fraud diamond theories have been criticized severally as being too generic in providing justification for the complex issues of financial crimes and fraud (Sadaf et al., 2018). The fact that the two theories consider only one physiological dimension of the initial perpetrator of fraud has also been criticized as being too narrow (Albrecht, Albrecht, \& Albrecht, 2008). Previous studies have made attempts to investigate other plausible factors that cause fraud that highlight not only the individual factors, but social and economic factors too (Free, 2015). Morales, Gendron, and Guénin-Paracini (2014) argue that an investigation into fraud detection and prevention should concentrate on the comprehensive roles of society and governance institutions. Conversely, Ramamoorti et al. (2009) proposes the ABC model, which approaches fraud as the interplay of bad individual (apple), collusion by several bad individuals (bushel) and bad cultural/societal mechanisms (Culture). According to Cieslewicz (2012) understanding fraud requires a consideration of societal-level influences, which differ from country to country. Accordingly, the need for further studies to explain fraud from international and governance perspective to bring to bear the differences in societal influences to inform international judgments cannot be overemphasized. This study, therefore, seeks to fill the gap from the perspective of OBOR countries, which are bound by multilateral value judgements.

The institutional quality concept relates to corporate bodies faced with the dilemma of increasing fraud. Usually multinational corporations (MNCs) that operate in different countries encounter dual institutional pressures from the host country as well as the home country (Hillman \& Wan, 2005). These MNCs are faced with the responsibility to conform to institutional norms and practices of both countries to be accepted in the host country and to realize their goal of enhancing performance (Suchman, 1995). Nonetheless, subsidiaries are bound to institutions of host countries that are ingrained in the different culture, values and norms, which constitute critical factors in decision making (Shi, Magnan, \& Kim, 2012) and can ultimately impact on fraud. The coercive power of governance is expected to protect lives, property and liberty rights.

Economists view institutions as "the rules of the game in a society or, more formally, are the humanly devised constraints that shape human interactions" (North, 1990). In sociological context, institutions are the "cultural- 
cognitive, normative, and regulative elements that, together with associated activities and resources, provide stability and meaning to social life" (Scott, 2001). Institutional theory submits that due to the fact that institutions are the rules of the game, they inform the decisions taken by firm managers (Suchman, 1995). Managers and corporations which breach the rules, thus, risk losing legitimacy to function. On the basis of institutional theory, we can anticipate that reported cases of accounting fraud in countries with quality institutions and effective governance systems will be minimal.

\subsection{Empirical Perspective}

Various studies have considered the phenomenal increasing trend in the level of fraud cases all over the world. Some of these studies examine the rationale behind fraud commission leading to factors that cause fraud. Others also discuss the consequence of increasing levels of fraud (Krambia-Kapardis, 2016). An unabated rising level of cases of fraud can lead to financial crises, which can affect several economies (Krambia-Kapardis, 2016). According to Cieslewicz (2012) fraud has an international face as a global issue, which varies across jurisdictions. There have also been efforts to examine the effects of accountability, governance, and other institutional determinants on the level of reported frauds (Máté et al., 2019; Sadaf et al., 2018).

Accounting fraud is a problem that hinders the usefulness of accounting information, and has been variously defined. The International Standards on Auditing 240 (ISA 240) defines accounting fraud as an intentional act executed by one or more persons who are part of the management, or those responsible for the governance of the entity, or employees or third parties, which involves the use of deception in order to gain an unfair or illegal advantage (IFAC, 2013). Thus, the perpetrators of fraud are usually management, employees (such as accountants), and third parties who commit the act for varied reasons. Top management may want to deceive other critical stakeholders or may seek to access more favorable financing or avoiding debt obligations (Reurink, 2016). In this study, we consider accounting fraud to cover the three primary categories of fraud - asset misappropriation, financial statement fraud and corruption - as outlined by the ACFE (ACFE, 2018).

Asset misappropriation is a fraud scheme which involves the theft of an entity's resources by employees in relatively small and immaterial amounts (IFAC, 2013). This usually includes stealing of the entity's cash, embezzling receipts, stealing physical assets or intellectual property, and inflated expense reports. Nonetheless, management may also involve in misappropriation of assets by disguising or concealing in complex ways, making the act difficult to detect. Asset misappropriation constitutes the most prominent form of occupational fraud with about 89 percent rate of occurrence (ACFE, 2018). Corruption refers to the misuse of power and influence of employees in business dealings for personal gain against duty to the employer (ACFE, 2018). It involves the employee using his or her business position to gain a benefit, through bribery, illegal gratuities, economic extortion and conflicts of interest. Financial statement fraud involves intentional misstatements including omissions of amounts or disclosures in financial statements to deceive users of accounting information (IFAC, 2013).

Although governance has been topical, there has been no consensus or a widely acceptable definition of the concept. Kaufmann, Kraay, and Mastruzzi (2011) define governance as "the traditions and institutions by which authority in a country is exercised”. Thus, governance refers to how a country is ran through designed policies and procedures that regulate the economic and social interactions of citizens. In recent times, researchers and policymakers all over the world have largely employed the Worldwide Governance Indicators (WGI) to measure governance, though there have been various criticisms in terms of the limitations in the methodologies that underpin their construction. According to Kaufmann, Kraay, and Mastruzzi (2010) the WGI comprises six composite indicators of broad dimensions of governance constructed since 1996 for over 200 countries. They include voice and accountability, political stability and absence of violence/terrorism, government effectiveness, regulatory quality, rule of law, and control of corruption. Various researchers have utilized these indicators in different forms of studies to represent governance. Shao, Ivanov, Podobnik, and Stanley (2007) examine the 
association between corruption and economic factors, such as wealth of a country and foreign investment per capita. They observe a negative relationship between the level of corruption in a country and long-run economic growth.

Competitiveness relates to the set of institutions, policies, and constraints that influence productivity of an economy (Schwab, 2018). The International Institute of Management Development (IMD) publishes World Competitiveness Yearbook (WCY), which ranks nations on various criteria that involve 20 sub-factors grouped into four major factors (Bhawsar \& Chattopadhyay, 2015). The World Economic Forum (WEF) also launched the Global Competitive Report (GCR) in 1979. Since 2004, the GCR features the global competitiveness index (GCI), which ranks countries based on their scores in 12 pillars, which are based on more than 100 different measures (Schwab, 2018). Despite the GCI being one of the most highly accepted and recognized indicators of competitiveness, there are some criticisms. While Berger and Bristow (2009) point to the absence of a sound theoretical basis for choosing variables as the most critical limitation to the GCI, Lall (2001) contends that definitions used are too broad and the methodology is flawed and biased. Despite the limitations, the GCI has been widely used to measure competitiveness of economies at various levels.

The GCI is widely recognized as a comprehensive and robust measure of competitiveness of economies. Podobnik, Horvatić, Kenett, and Stanley (2012) base on the GCI to develop relative competitiveness, a new measure to assess an economy's competitiveness relative to GDP. They examine how a country's relative competitiveness affects its wealth during recession. Focusing on European and EU economies over the 2008-2011 period of economic downturn, the authors observe that more competitive economies experienced a lesser drop in GDP than less competitive economies. Chukwunedu, Okafor, and Oraka (2012) also investigate the effect of management fraud on the global competitiveness of the Nigerian banking industry. Using falsification of financial statements, contribution to the collapse of capital market and capital flight to represent management fraud, they find that all the three variants negatively influence the country's competitiveness proxied by flow of foreign direct investment (FDI). Sadaf et al. (2018) seek to ascertain the influence of GCI on accounting crimes and find that countries that were competitive witnessed more accounting fraud. Thus, their study posits that GCI of economies positively influenced the number of accounting fraud cases.

According to Královičová and Zatko (2016) if the OBOR initiative operates as intended it will enhance the global competitiveness of participating countries. Harrison and Huntington (2000) contend that cultural factors promote growth and competitiveness of East Asian economies. Prior studies examine the competitiveness of China at the macro level (Adams, Gangnes, \& Shachmurove, 2006; El-Namaki, 2002; Zhao \& Zhang, 2007), and the competitiveness at industry level (Liu, Xu, \& Zhang, 2010; Yang, Ji, Nie, \& Yinxing, 2013). The overall competitive landscape of most OBOR countries shows a positive picture, while others show a very terrible picture. From 2nd position behind the US in 2017, Singapore ranks 1st with 84.8 score; China still ranks 28 th with a score of 73.9 , India at 68 th with 61.4 score, Iran ranked at 99th position, and Yemen at the bottom, 140th position with a score of 35.5 (World Economic Forum, 2019). The variation in competitiveness of these countries necessitates a look at the occurrence of accounting fraud and whether the state of competitiveness affects fraud in those economies.

\subsection{Hypotheses Development}

Prior studies have linked governance to institutions, viewing governance as the functioning of formal and informal institutions in the management of state resources (Huther \& Shah, 1996; Kaufmann, Kraay, \& Mastruzzi, 2003; Kaufmann, Kraay, \& Zoido-Lobatón, 1999). This linkage has necessitated the very prominent and widely used set of governance indicators (Zhuang, de Dios, \& Martin, 2010). Though Haq and Zia (2009) breaks governance into political, economic and institutional governance, Barro (1991); Knack and Keefer (1995) and Zhuang et al. (2010) have all used governance indicators to proxy institutional quality. Thus, the reference of governance to the notion of institutions assumes that governance indicators are useful in measuring institutional quality. While emphasizing that a country's growth trajectory is often shaped by the quality of its institutions generally, Siyakiya 
(2017) notes that there are exceptional cases. The author mentions the example of China, where high growth rates are recorded despite the institutional rating issues. Generally, when institutional quality is low in an environment with weak protection for property rights and lesser punishment for fraudulent behaviour, people tend to become dishonest (Asgharian, Liu, \& Lundtofte, 2014) which can ultimately affect the occurrence of fraud. On the other hand, in an environment with high institutional quality, where property rights are well protected and stiffer punishment is meted out to perpetrators of fraud, the occurrence of fraud reduces. This study, thus, hypothesizes as follows.

$H_{1}$ : There is a statistically significant negative relationship between world governance indicators and the level of fraud of OBOR countries

Chukwunedu et al. (2012) represent competitiveness by the flow of FDI and note that fraud negatively affects competitiveness. The authors consider three variants of fraud and all showed negative effect on the flow of FDI. The GCI ranks countries based on their efforts to drive productivity and growth. It emphasizes the role of human capital, innovation, resilience and agility, as essential drivers and defining features of economic success of countries. The GCI is measured by the scores from 1 to 7 , where a higher average score denotes a higher degree of competitiveness. Amar and Hamdi (2012) submits that there is a statistically significant positive relationship between economic growth and global competitiveness among African countries. Sadaf et al. (2018) observe that global competitiveness positively affects the number of fraud cases and that countries that were more competitive reported more cases of fraud. Thus, their study posits that GCI of economies positively influenced the number of accounting fraud cases. While observing a general unidirectional causality from economic growth to competitiveness, Kordalska and Olczyk (2015) also note that competitiveness leads to growth among large economies like the United States, China, India and Russia. Countries that score high on the various levers of competitiveness are likely to attract more investments and will more likely strive to protect investors to have value for their investments. Thus, high competitiveness scoring will help to reduce occurrence of fraud. This study, therefore, formulates the following hypothesis.

$H_{2}:$ There is a statistically significant negative relationship between global competitiveness index and the level of fraud of OBOR countries.

\subsection{Conceptual Framework}

The framework of this study is shown in Figure 1 and depicts a relationship between governance indicators, global competitiveness and accounting fraud. Governance indicators and global competitiveness constitute independent variables with regime type and economic growth as control variables while accounting fraud is the dependent variable. The study includes six indicators - control of corruption (CoC), political stability (PoS), government effectiveness (GEf), regulatory quality (ReQ), rule of law (RoL) and voice and accountability (VoA) - as measures of governance. As shown in Figure 1 we posit that the world governance indicators and global competitiveness of countries influence their level of accounting fraud. The inclusion of the two control variables is justified by the fact that those variables also influence the dependent variable, accounting fraud.

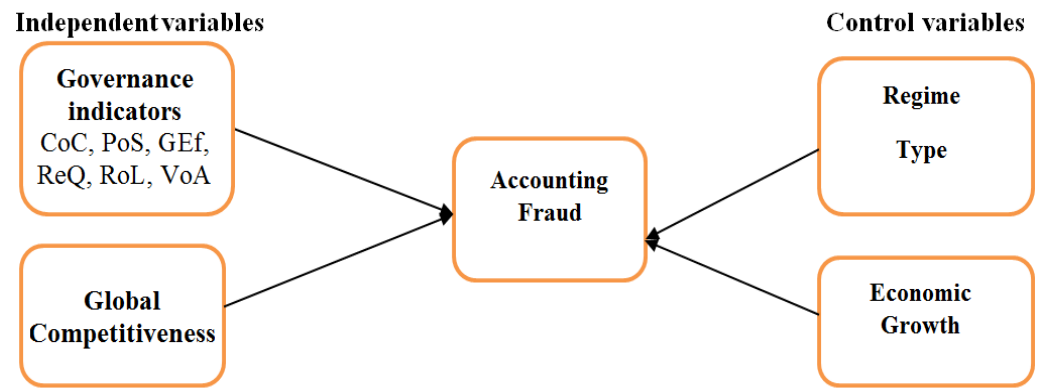

Figure-1. Conceptual framework. 


\section{DATA AND METHODOLOGY}

The sample comprises a cross section of 65 OBOR countries (as shown in Appendix I). Two reasons justify the selection of the 65 countries. First, data for all the governance indicators are available for these countries, while data on the level of accounting fraud cases of international nature are available for the countries over the study period. Second, the countries are selected given the fact that they form part of a major initiative by the People's Republic of China to ensure global cooperation towards improved world economic output. China and the other 64 countries account for $62 \%$ of the world's population and 30\% of world economic output (Huang, 2017). Table 1 provides a description of the various variables included in the study and the sources of data used in the study. Adapting the methodology of Sadaf et al. (2018) we employ a panel data estimation technique (linear regression model) to depict a relationship between governance indicators and global competitiveness and accounting fraud. The function specified in Equation 1 indicates that the level of accounting fraud is a function of the six worldwide governance indicators and global competitive indicators; Equation 2 also specifies the logarithm for of Equation 1.

$$
\begin{aligned}
& \text { Fraud }=f(C o C, \text { PoS, GEf, ReQ RoL, VoA, GCI }) \\
& \ln (\text { Fraud })_{i t}=\alpha_{o}+\beta_{i} C_{o} C_{i t}+\beta_{2} P o S_{i t}+\beta_{3} G E f_{i t}+\beta_{4} \operatorname{Re} Q_{i t}+\beta_{5} R_{o} L_{i t}+\beta_{6} V o A_{i t} \\
& +\beta_{7} \ln (G C I)_{i t}+\beta_{s} \ln (G D P)_{i t}+\beta_{9} R e T_{i t}+\mathcal{E}_{i t}
\end{aligned}
$$

where $i$ refers to a country, $t$ denotes time and the variables are as defined in Table 1. Following Sadaf et al. (2018) we undertake the log transformation of fraud, global competitiveness and GDP to ensure validity and correct skewed data. Since Kaufmann et al. (2010) normalizes the data on governance indicators, we do not transform those measures.

Table-1. Description of variables.

\begin{tabular}{l|l|c|c}
\hline Variable & Definition & Source & Expected sign \\
\hline Fraud & Level of Fraud & ACFE & $\mathrm{n} / \mathrm{a}$ \\
\hline CoC & Control of Corruption & WGI (2018) & -ve \\
\hline PoS & Political Stability & WGI (2018) & -ve \\
\hline GEf & Government Effectiveness & WGI (2018) & -ve \\
\hline ReQ & Regulatory Quality & WGI (2018) & -ve \\
\hline RoL & Rule of Law & WGI (2018) & -ve \\
\hline VoA & Voice and Accountability & WGI (2018) & -ve \\
\hline GCI & Global Competitive Index & WEF (2018) & -ve \\
\hline GDP & Gross Domestic Product & WDI (2018) & -ve \\
\hline ReT $\beta_{1}-\beta_{7}$ & Regime type Coefficients of independent & World Bank (2018) - & + ve/-ve \\
\hline Ln & variables & & \\
\hline$\varepsilon$ & Natural logarithm & - & - \\
\hline
\end{tabular}

\subsection{Dependent Variable}

Fraud represents the number of fraud cases reported by countries and obtained by the Association of Certified Fraud Examiners (ACFE). Other fraud cases not published by the ACFE are not under consideration; nonetheless, the ACFE provides widely recognized data on fraud. ACFE has been biannually publishing the Report to the Nation on Occupational Fraud and Abuse since 1996. The level of fraud cases has been gathered from the last five biannual reports - 2010, 2012, 2014, 2016 and 2018. The ACFE is a professional body for fraud examiners. The body is recognized as the world's largest anti-fraud organization and premier provider of anti-fraud training, education and certification (ACFE website). Some earlier empirical work has employed the ACFE data to study fraud (e.g., (Bishop, Hermanson, \& Riley, 2017; Fleming, Hermanson, Kranacher, \& Riley, 2016)) and observed the relevance of the data. Table 2 shows a distribution of cases of occupational fraud according to geographic regions, with 102 countries in 2016 and 125 countries in 2018. North America made up of only the USA and Canada recorded the highest proportion of cases (52.8 percent in 2016 and 51.7 percent in 2018), followed by Sub-Saharan Africa (13.8 percent in 2016 and 12.8 percent in 2018). In 2016, the Middle East and North Africa (MENA) 
recorded the lowest (3.7 percent) but Eastern Europe and Western/Central Asia recorded the lowest (4.1 percent) in 2018 .

Table-2. Fraud cases by geographic regions.

\begin{tabular}{|c|c|c|c|c|}
\hline & \multicolumn{2}{|c|}{2016} & \multicolumn{2}{|c|}{2018} \\
\hline & Frequency & Percent & Frequency & Percent \\
\hline Asia-Pacific & 221 & 10.4 & 220 & 10.5 \\
\hline Latin America and the Caribbean & 112 & 5.3 & 110 & 5.3 \\
\hline Middle East and North Africa & 79 & 3.7 & 101 & 4.8 \\
\hline Southern Asia & 98 & 4.6 & 96 & 4.6 \\
\hline Sub-Saharan Africa & 285 & 13.4 & 267 & 12.8 \\
\hline Western Europe & 110 & 5.2 & 130 & 6.2 \\
\hline Total & 2127 & 100.0 & 2092 & 100.0 \\
\hline
\end{tabular}

Figure 2 shows a pictorial breakdown of fraud cases by regions as reported by the ACFE in 2016. As can be seen, North America, which consists of the US and Canada alone recorded 52.8 percent of fraud cases that were of international status. Most of the 65 OBOR countries belong to Asia-Pacific, Southern Asia and MENA, which jointly recorded 18.7 percent, which constituted 45.4 percent of the number of fraud cases recorded excluding the US and Canada.

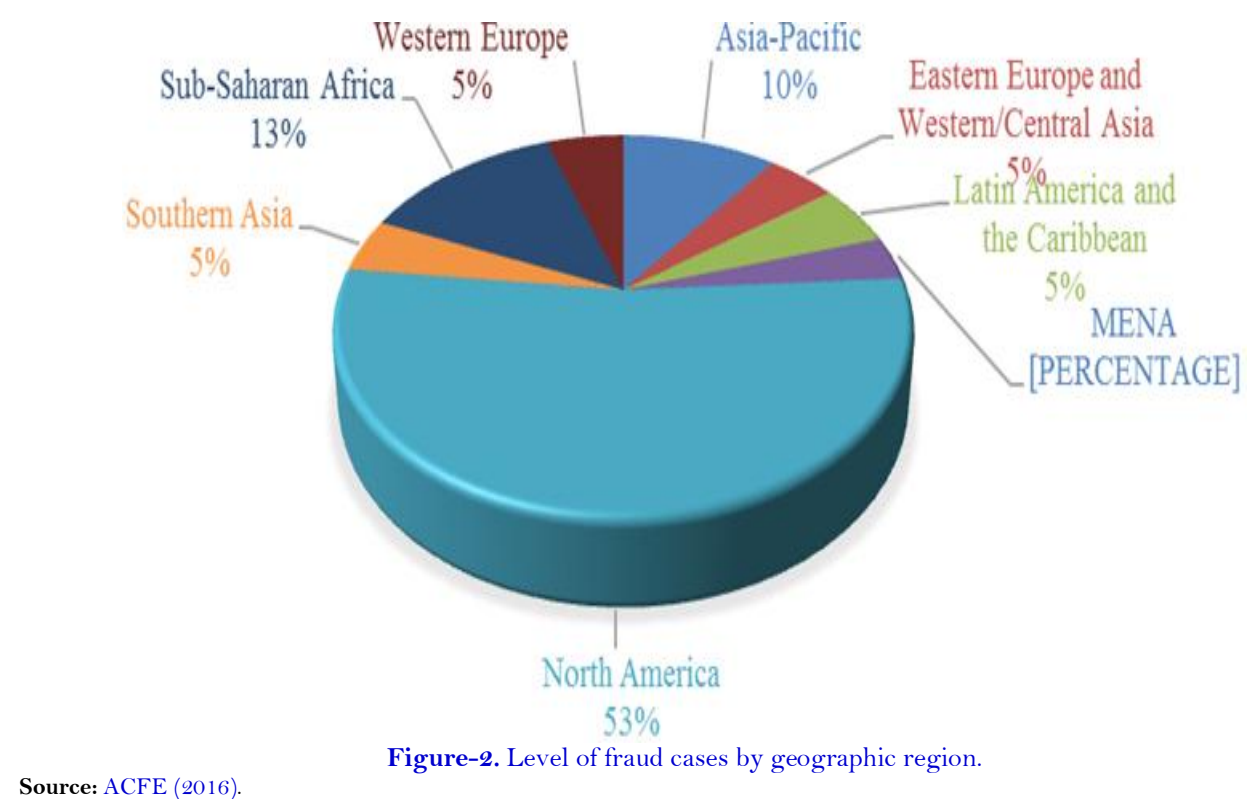

Figure 3 also depicts a pictorial breakdown of the number of fraud cases by geographic regions as reported by the ACFE in 2016. As can be seen, North America, which consists of the US and Canada alone recorded 52 percent of fraud cases that were of international status. In 2018, the three OBOR regions jointly recorded 19.9 percent of the total number of fraud cases, which constituted 41.2 percent of the fraud cases excluding the US and Canada. In absolute terms, the number of fraud cases recorded in the OBOR regions rose from 18.7 in 2016 to 19.9 in 2018. This raises concern about the fraudulent activities in those countries and their potential risk to the BRI aimed at enhancing global cooperation and world productivity. 


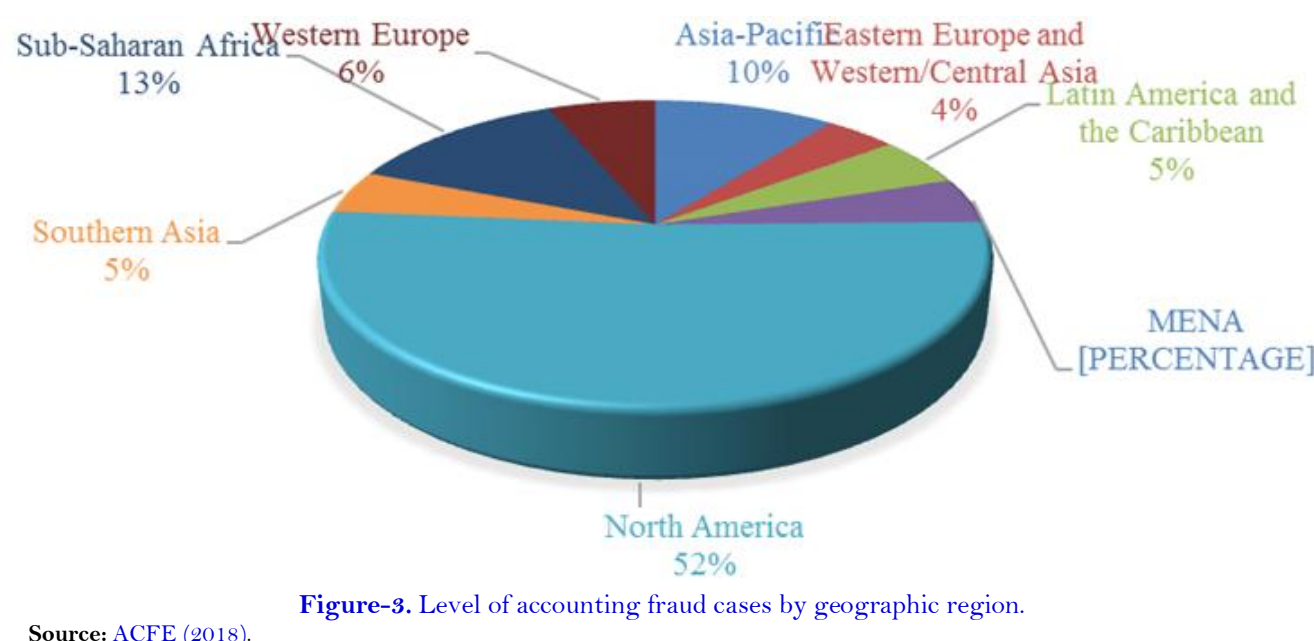

\subsection{Independent Variables}

Two main independent variables - governance infrastructure and global competitiveness - are included in our model. The Worldwide Governance Indicators (WGI) project by the World Bank, constructs aggregate and standardized indicators which serve as comprehensive dimensions of governance. According to Kaufmann et al. (2010) these composite indicators are based on about 31 fundamental data sources reporting the perceptions of governance of a greater number of respondents as well as expert assessments worldwide. They include Control of Corruption, Government Effectiveness, Political Stability and Absence of Violence/Terrorism, Regulatory Quality, the Rule of Law and Voice and Accountability. Prior studies such as Haq and Zia (2009) and Sadaf et al. (2018) have employed these indicators as proxies for good governance.

Control of Corruption indicates "the perceptions of the extent to which public power is exercised for private gain, including both petty and grand forms of corruption as well as "capture" of the state by elites and private interests" (Kaufmann et al., 2011; World Governance Indicators (WGI), 2018). Political Stability and Absence of Violence "measures the perceptions of the likelihood of political instability and/or politically-motivated violence, including terrorism” (Kaufmann et al., 2011; World Governance Indicators (WGI), 2018). Government Effectiveness "captures the perceptions of the quality of public services, the quality of the civil service and the degree of its independence from political pressures, the quality of policy formulation and implementation, and the credibility of the government's commitment to such policies" (Kaufmann et al., 2011; World Governance Indicators (WGI), 2018).

Regulatory Quality "captures the perceptions of the ability of the government to formulate and implement sound policies and regulations that permit and promote private sector development" (Kaufmann et al., 2011; World Governance Indicators (WGI), 2018). The index covers price controls, banking supervision and the regulation of foreign trade and business development. Rule of Law "captures the perceptions of the extent to which agents have confidence in and abide by the rules of society, and in particular the quality of contract enforcement, property rights, the police, and the courts, as well as the likelihood of crime and violence" (Kaufmann et al., 2011; World Governance Indicators (WGI), 2018). The index gauges perceptions with respect to incidence of crime, the effectiveness and predictability of the judiciary, and the enforceability of contracts. Voice and accountability "capture the perceptions of the extent to which a country's citizens are able to participate in selecting their government, as well as freedom of expression, freedom of association, and a free media" (Kaufmann et al., 2011; World Governance Indicators (WGI), 2018). The index concerns all aspects of the political process, civil liberties and political rights as well as the independence of the media.

Global competitiveness represented by World Economic Forum's Global Competitiveness Index (GCI), considers several factors such as country's institutions, policies, macroeconomic environment, social services 
(health, education and training), market size and efficiency, financial market development, business sophistication, and innovation, etc. The index by WEF scores countries from 1 to 7 to measure competitiveness; higher score indicates high competitiveness while a lower score indicates low competitiveness (Schwab, 2018). Studies like Korez-Vide and Tominc (2016) use the same proxy.

\subsection{Control Variables}

Our model incorporates two control variables - economic growth and regime type. Economic growth measured by the growth of GDP per capital is obtained from the World Development Indicators (World Bank, 2019). Economic growth is controlled because the GDP per capital of a country may influence the occurrence of accounting fraud in that country. For instance, Goulas and Zervoyianni (2015) indicate that the state of the economy matters when it comes to the relationship between per capita growth and accounting crimes. Regime type $(\mathrm{ReT})$ represents a dummy variable which denotes the nature of regime practised by a country, whether democratic or non-democratic; $1=$ democratic and $0=$ non-democratic. The justification of the inclusion of ReT is that the form of governance regime of a nation may affect the existence of accounting fraud cases.

\subsection{Robustness Checks}

To ensure that we do not generate spurious results that may have validity issues, we employ varied techniques to subject the data to robustness test. We run Shapiro-Wilk data normality test to ascertain if the data is normally distributed or otherwise. The Doornik-Hansen test for multivariate normality strengthened the validity of normal distributions in both cases. We also deal with multicollinearity among the explanatory variables by performing a principal component analysis (PCA) to reduce the dimensions of our governance indicators. In order to avoid heteroskedasticity in our results, we control for heteroskedasticity in all our estimations to arrive at robust results.

By using panel data for the study, we determine the suitability of fixed and random effects models through the Hausman post-estimation test. The Hausman test has the null hypothesis that individual effects are uncorrelated with any regressor in the model as against the alternative hypothesis that individual effects are significantly correlated with at least one regressor in the mode (Hausman, 1978; Park, 2011). In all our scenarios, we perform Hausman post-estimation tests. In models $1,3,4$ and 5 , the outcome of the Hausman test is not significant, which means we fail to reject the null hypothesis that random-effects model is suitable and arrive at the conclusion that fixed-effects model is not suitable. The random effects model is chosen if there is a justification to believe that differences across entities have some influence on the dependent variable. We specify the random effect model as shown in Equation 3:

$$
\mathrm{Y}_{\mathrm{it}}=\beta_{1} X_{i t}+\alpha_{0}+\mu_{i t}+\varepsilon_{\mathrm{it}}
$$

where $\alpha_{0}$ is the intercept for each entity, $\mu_{i t}$ is the between-entity error and $\varepsilon_{i t}$ is the within-entity error. While $\beta_{1}$ is the vector of the coefficients, $X_{i t}$ is the vector of the explanatory variables.

The outcome of the tests ran for models 2, 6, 7 and 8 indicate that the estimates of the fixed effects model should be preferred to that of the random effects model. The outcomes of the Hausman tests here are significant, which means a rejection of the null hypothesis that random-effects model is suitable. We conclude that the alternative hypothesis that fixed-effects model is rather suitable in those scenarios is accepted. The fixed-effects model is preferred if there is enough reason to believe that the entities' error term and the intercept, which captures the individual characteristics, are not correlated with the others. We specify the fixed-effects model as shown in Equation 4:

$$
\mathrm{Y}_{\mathrm{it}}=\beta_{1} X_{i t}+\alpha_{0}+\mu_{i t}
$$

where $\alpha_{0}$ is the unknown intercept for each entity, $\mu_{i t}$ is the error term. While $\beta_{1}$ is the vector of the coefficients, $X_{i t}$ is the vector of the explanatory variables. 


\section{RESULTS AND DISCUSSION}

\subsection{Descriptive Statistics}

Some descriptive statistics of the variables included in the study are shown in Table 3. The total observations estimated for the study was 185 determined as five years for 37 OBOR countries. Even though we initially targeted all the 65 OBOR countries, some of those countries were not included in the ACFE datasets for fraud reporting. The frequency of the data was biannual from 2010 to 2018 for 37 countries, which comes to 185 observations. We consider some descriptive items which include the mean, standard deviation, minimum and maximum values. We also report skewness, which measures asymmetry and kurtosis, which measures the tallness or flatness of a probability distribution function.

Accounting fraud recorded a mean of 1.5146 cases with a standard deviation of 1.1518 , which suggests that the level of fraud cases deviated from the mean by 1.1518, an indication that the fraud data were widely dispersed from the average. The level of fraud also recorded a minimum of 0 and a maximum of 4.34 with a variance of 1.33. In terms of skewness, fraud was positively skewed with a value of 0.3873 , with the distribution function on the right. A kurtosis of 2.2782 for fraud implies that the distribution is fat or short-tailed (platykurtic). The average control of corruption was 47.64 with a standard deviation of 23.27 , a minimum of 0.95 and a maximum of 98.57. Like control of corruption, all the other governance indicators recorded very high standard deviation, which meant that governance data were widely dispersed from the averages. While the average government effectiveness and regulatory quality exceeded 50 percent, voice and accountability recorded the lowest average of 38.8 though control of corruption and political stability recorded mean indices of 47.64 and 40.93 respectively. Global competitiveness index of the countries over time saw a mean of 1.4768 and a standard deviation of 0.1057 , which means that the data across the countries did not widely deviate from their means.

With the exception of political stability and voice and accountability, all the governance indicators were negatively skewed, which suggests that the probability distribution function was left. Again, GDP was also negatively skewed but global competitive index was positively skewed, which means the probability distribution function was right. In terms of kurtosis, with the exception of GDP, all the variables recorded kurtosis values less than 3 (as shown in Table 3), which indicates fat or short-tailed probability distribution function (platykurtic). GDP, however, recorded kurtosis value of 11.5162 , which was greater than 3 for normal distribution. It was, therefore, the only variable that was leptokurtic (slim or long-tailed).

Table-3. Descriptive summary.

\begin{tabular}{c|l|c|c|c|c|c|c|c|c}
\hline Stats & $\begin{array}{l}\text { Ln } \\
\text { FRAUD }\end{array}$ & CoC & PoS & GEf & ReQ & RoL & VoA & $\begin{array}{l}\text { ln } \\
\text { GCI }\end{array}$ & $\begin{array}{l}\text { In } \\
\text { GDP }\end{array}$ \\
\hline $\mathrm{N}$ & 185 & 185 & 185 & 185 & 185 & 185 & 185 & 179 & 144 \\
\hline Mean & 1.5146 & 47.6365 & 40.9294 & 56.7999 & 56.2102 & 51.7165 & 38.8089 & 1.4768 & 1.0781 \\
\hline Minimum & 0 & 0.95 & 0.47 & 4.78 & 5.26 & 0.47 & 2.82 & 1.2296 & -3.9120 \\
\hline Maximum & 4.3438 & 98.57 & 99.05 & 100 & 100 & 96.63 & 87.2 & 1.7440 & 2.5265 \\
\hline Std. Dev & 1.1518 & 23.2715 & 27.5304 & 20.5036 & 21.3066 & 21.6764 & 23.3354 & 0.1057 & 0.8643 \\
\hline Variance & 1.3267 & 541.5646 & 757.9228 & 420.3962 & 453.97 & 469.8668 & 544.5409 & 0.0112 & 0.7470 \\
\hline Kurtosis & 2.2782 & 2.2131 & 1.8529 & 2.8857 & 2.5586 & 2.3703 & 1.9085 & 2.9722 & 11.5162 \\
\hline Skewness & 0.3873 & -0.0305 & 0.2657 & -0.3149 & -0.3665 & -0.2293 & 0.3186 & 0.2168 & -0.1947 \\
\hline
\end{tabular}

\subsection{Correlational Analysis}

Table 4 presents the correlation matrix, which reports correlations among some of the independent variables. Nonetheless, this study does not seek to examine causal relationship and does not focus on endogeneity and omitted variables since panel data analysis, by its statistical nature, usually addresses collinearity concerns (Ranjan \& Agrawal, 2011). The correlational analysis revealed that control of corruption, government effectiveness, global competitiveness and economic growth all had significant positive correlation with the level of fraud. This indicates that whenever CoC, GEf, lnGCI and lnGDP increased, the level of fraud also increased and vice versa. Control of 
corruption, government effectiveness, global competitiveness and economic growth recorded correlation coefficients of $0.1541,0.2313,0.3973$ and 0.0735 respectively, which all showed weak correlation with the level of fraud, as none of them was up to the threshold of 0.8 to be deemed strong.

Table-4. Correlation matrix.

\begin{tabular}{|c|c|c|c|c|c|c|c|c|c|}
\hline & lnFraud & $\mathrm{CoC}$ & PoS & GEf & $\operatorname{ReQ}$ & RoL & VoA & $\ln \mathrm{GCI}$ & GDP \\
\hline lnFraud & 1.0000 & & & & & & & & \\
\hline $\mathrm{CoC}$ & $\begin{array}{r}0.1541^{*} \\
0.0363 \\
\end{array}$ & 1.0000 & & & & & & & \\
\hline $\mathrm{PoS}$ & $\begin{array}{r}-0.0756 \\
0.3067 \\
\end{array}$ & $\begin{array}{l}0.7172^{*} \\
0.0000\end{array}$ & 1.0000 & & & & & & \\
\hline GEf & $\begin{array}{r}0.2313^{*} \\
0.0015\end{array}$ & $\begin{array}{l}0.9088^{*} \\
0.0000\end{array}$ & $\begin{array}{l}0.6888^{*} \\
0.0000\end{array}$ & 1.0000 & & & & & \\
\hline ReQ & $\begin{array}{r}0.0751 \\
0.3096\end{array}$ & $\begin{array}{l}0.8733^{*} \\
0.0000\end{array}$ & $\begin{array}{l}0.7110^{*} \\
0.0000\end{array}$ & $\begin{array}{c}0.9119^{*} \\
0.0000\end{array}$ & 1.0000 & & & & \\
\hline RoL & $\begin{array}{l}0.1143 \\
0.1214 \\
\end{array}$ & $\begin{array}{l}0.9564^{*} \\
0.0000\end{array}$ & $\begin{array}{l}0.7353^{*} \\
0.0000\end{array}$ & $\begin{array}{l}.9151^{*} \\
0.0000\end{array}$ & $\begin{array}{l}0.9029 * \\
0.0000\end{array}$ & 1.0000 & & & \\
\hline VoA & $\begin{array}{r}-0.0489 \\
0.0489\end{array}$ & $\begin{array}{l}0.3398^{*} \\
0.0000\end{array}$ & $\begin{array}{l}0.4037^{*} \\
0.0000\end{array}$ & $\begin{array}{l}.3624^{*} \\
0.0000\end{array}$ & $\begin{array}{l}0.4747^{*} \\
0.0000\end{array}$ & $\begin{array}{l}0.4112^{*} \\
0.0000\end{array}$ & 1.0000 & & \\
\hline $\ln \mathrm{GCI}$ & $\begin{array}{r}0.3973^{*} \\
0.0000\end{array}$ & $\begin{array}{l}0.7349^{*} \\
0.0000\end{array}$ & $\begin{array}{l}0.4712^{*} \\
0.0000\end{array}$ & $\begin{array}{l}.7979^{*} \\
0.0000\end{array}$ & $\begin{array}{l}0.6401^{*} \\
0.0000\end{array}$ & $\begin{array}{l}0.6978^{*} \\
0.0000\end{array}$ & $\begin{array}{r}-0.0352 \\
0.6403 \\
\end{array}$ & 1.0000 & \\
\hline $\ln \mathrm{GDP}$ & $\begin{array}{l}0.0735^{*} \\
0.0155\end{array}$ & $\begin{array}{l}-0.2170^{*} \\
0.0090\end{array}$ & $\begin{array}{r}-0.1053 \\
0.2092\end{array}$ & $\begin{array}{r}-0.1421 \\
0.0894\end{array}$ & $\begin{array}{l}-0.2121^{*} \\
0.0107\end{array}$ & $\begin{array}{l}-0.1979^{*} \\
0.0174\end{array}$ & $\begin{array}{r}-0.0387 \\
0.6452\end{array}$ & $\begin{array}{l}0.0574 \\
0.4989\end{array}$ & 1.0000 \\
\hline
\end{tabular}

To ensure validity of the findings, we performed multicollinearity test to determine if some of the predictors were themselves correlated. Multicollinearity is said to occur when explanatory variables are correlated and provide spurious information as to their predictive value on the explained variable. Kuwornu (2012) suggests that a range of -0.70 to +0.70 recorded in a correlation matrix is acceptable. Thus, multicollinearity exists if a pairwise correlation exceeds 0.70 in a matrix. This rule was applied to the results of the correlation analysis as shown in Table 4 and the results show that some of the explanatory variables were highly correlated, which implies the existence of multicollinearity between those variables. For instance, RoL shows strong significant correlation with most of the explanatory variables such as $\mathrm{CoC}(\mathrm{r}=0.9564)$, PoS $(\mathrm{r}=0.7353)$, GEf $(\mathrm{r}=0.9151)$ and $\mathrm{ReQ}(\mathrm{r}=0.9029)$. while lnGCI had significant correlation with all other variables, except VoA, the coefficients of 0.7349 and 0.7979 for CoC and GEf respectively indicate collinearity with lnGCI. Again, CoC recorded significant correlation with all other variables except lnGDP and was collinear with five of the variables showing coefficients above 0.7. The coefficients included $(r=0.7172)$ for PoS, $(r=0.9088)$ for GEf, $(r=0.8733)$ for ReQ, $(r=0.9564)$ for RoL and $(r=0.7349)$ for lnGCI. Almost all of the independent variables were correlated and most of them were highly correlated. That implies that multicollinearity was a problem in our dataset.

Further, the variance of inflation factor (VIF) or the degree of tolerance (1/VIF) technique was also used to test for and confirm the existence multicollinearity. The rule of thumb has it that variables with a VIF greater than 5 $(\mathrm{VIF}>5)$ or a degree of tolerance less than $0.2(1 / \mathrm{VIF}<0.2)$ are deemed to be highly collinear. From Table 5 , it can be seen that four of our governance indicators (RoL, GEf, $\mathrm{CoC}$ and ReQ) are highly collinear. This depicts the existence of multicollinearity, which is consistent with the outcome of the test with respect to our correlational analysis.

\subsection{Data Normality Test}

The normality of data of variables involved in a study is among the suitable assumptions in data analysis. Different techniques can be employed to determine whether data in a study are normally distributed or otherwise. We perform the Shapiro and Wilk (1965) test for normality to test for data normality. In a Shapiro-Wilk test, the 
null hypothesis has it that the sample data are normally distributed. As shown in Table 6, all the variables were significant, which means that we reject the null hypothesis and conclude that the sample data were not normally distributed.

Table-5. VIF and tolerance test results.

\begin{tabular}{l|c|c}
\hline Variable & VIF & $\mathbf{1 / V I F}$ \\
\hline RoL & $15.46^{*}$ & 0.064680 \\
\hline GEf & $13.01^{*}$ & 0.076887 \\
\hline CoC & $12.86^{*}$ & 0.077742 \\
\hline ReQ & $8.15^{*}$ & 0.122667 \\
\hline $\operatorname{lnGCI}$ & 3.87 & 0.258305 \\
\hline PoS & 2.13 & 0.470292 \\
\hline VoA & 1.94 & 0.514679 \\
\hline $\operatorname{lnGDP}$ & 1.10 & 0.906356 \\
\hline Mean VIF & 7.32 & \\
\hline Note:* indicates the existence of multicollinearity. & &
\end{tabular}

Table-6. Shapiro-wilk test for normal data.

\begin{tabular}{l|c|c|c|c|c}
\hline Variable & Obs & $\mathbf{w}$ & $\mathbf{v}$ & $\mathbf{z}$ & Prob $>\mathbf{z}$ \\
\hline lnFRAUD & 185 & 0.96939 & 4.268 & 3.326 & 0.00044 \\
\hline CoC & 185 & 0.97915 & 2.907 & 2.446 & 0.00723 \\
\hline PoS & 185 & 0.94273 & 7.985 & 4.761 & 0.00000 \\
\hline GEf & 185 & 0.98579 & 1.981 & 1.566 & 0.05865 \\
\hline ReQ & 185 & 0.97878 & 2.958 & 2.486 & 0.00646 \\
\hline RoL & 185 & 0.98305 & 2.364 & 1.971 & 0.02435 \\
\hline VoA & 185 & 0.94443 & 7.748 & 4.692 & 0.00000 \\
\hline GDP & 185 & 0.98337 & 2.318 & 1.927 & 0.02700 \\
\hline $\ln$ GCI & 179 & 0.98545 & 1.971 & 1.553 & 0.06022 \\
\hline
\end{tabular}

\subsection{Principal Component Analysis}

We test the robustness of the estimates for governance through the study construction of three indexes from the six indicators of governance infrastructure by employing the principal components analysis (PCA) technique. Table 7 shows the outcome of the PCA. The first governance indicator from the six principal components explains about $76.08 \%$ of the total variance in the original data, while the indexes we create from the first three principal components explain about $96 \%$ of the variance in the data. This indicates that we have been able to reduce the dimension of the governance indicators by half while maintaining $96 \%$ of the content in the data. Our sub-indexes for governance constructed are orthogonal to each other and exhibit zero correlations with each other, which makes it plausible to include all of them in a single model. The first principal component index, Gov1 explains $76.08 \%$ of the total variance in the data. Adopting a scoring coefficient of 0.3 or above to decide on the significance of factor score, the first principal components could be deemed as denoting CoC, PoS, GEf, ReQ and RoL. VoA is excluded because it is deemed insignificant as its scoring coefficient in the component is far below 0.3. The second and third principal components (Gov2 and Gov3) respectively explain about $13.38 \%$ and $6.42 \%$ of the total variance in the data. The last three components explain very negligible portion of the total variance as the two sum up to $1.92 \%$. Using the 0.3 scoring coefficient criterion, Gov2 and Gov3 are composite indexes representing VoA and PoS respectively.

\subsection{Regression Results}

Table 8 presents the results of heteroscedasticity-corrected regression models ran to depict a relationship between accounting fraud, the dependent variable and the predictors. The results were obtained after reducing the dimension of our governance indicators by half and maintaining $95.87 \%$ of the content in the data through PCA. In all, eight models are presented in the table covering different scenarios with the preferred specific-effects model 
shown after several Hausman post-estimation tests ran. In the first scenario, we consider only the governance indices and determine their impact on the number of fraud cases.

Table-7. Results of principal components analysis

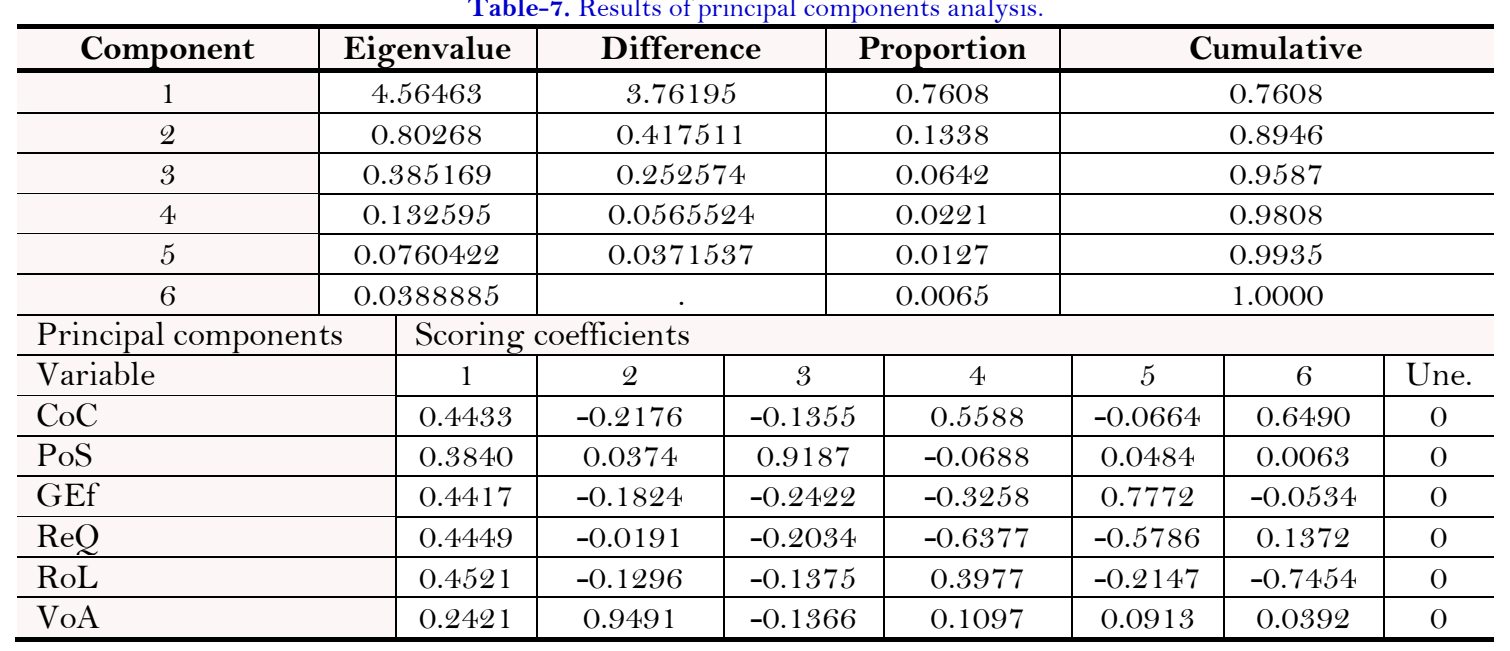

All the three governance indexes are statistically significant in explaining the number of fraud cases reported. While Gov 1 shows a significant positive influence on fraud, Gov2 and Gov3 show significant negative influence on fraud. The positive coefficient of Gov1 $(r=.0982)$ indicates the average effect of governance over the number fraud cases reported when governance index changes across time and between countries by one unit. The negative coefficients of Gov2 ( $\mathrm{r}=-.2810)$ and Gov3 ( $\mathrm{r}=-.3427)$ represent the average negative effect of the governance indexes over fraud cases reported when the governance indexes vary across time and between countries by one unit. Thus, a unit increase in Gov2 (VoA) and Gov3 (PoS) across time and between countries, leads to an average decrease of 0.28 and 0.34 respectively in fraud and vice versa. In the second scenario, we consider only the governance indices and global competitiveness without control variables (GDP and regime type). In models 3 and 5 , we include only a control variable each with the governance indexes but without the competitiveness index. In models 4 and 6 we run the governance indexes and competitiveness index with GDP and regime type dummy respectively. Whereas model 7 runs governance indexes with the two control variables inclusive but without competitiveness, model 8 includes all the variables serving as predictors of the number of fraud cases reported.

The results of our fixed effects in model 2 where we did not include control variables but only the governance indexes and the competitive index showed that Gov2 (made up of only voice and accountability) was statistically significant at $5 \%$ level of significance. The coefficient of $(\beta=-0.4652)$ indicated that the political stability had a significant negative effect on the level of fraud. Thus, for a given country when Gov 2 (VoA) improved by a unit, the number of fraud cases reduced by 0.4652 and vice versa. Gov1 (made up of all governance indicators except VoA), Gov3 (consisting of $\mathrm{PoS}$ ) and competitive index all showed a positive relationship with the level of fraud, except that they were all insignificant.

In model 3, we showed the random-effects regression results with only lnGDP and the governance indexes, without $\ln$ GCI. The results showed that Gov 1 was significant at $1 \%$ and Gov2 was also significant at $10 \%$. The coefficients, $(\beta=.1395)$ and ( $\beta=-.2628)$ for Gov1 and Gov2 respectively indicate that Gov1 had a positive effect with Gov2 had a negative effect on the number of fraud cases recorded. After including only one control variable (lnGDP), without the ReT dummy, the results of the random-effects regression (as in model 4) showed that only lnGCI was statistically significant at $5 \%$ level of significance. Though all the governance indexes showed negative association with fraud, they were statistically insignificant. The coefficient of $(\beta=3.7661)$ recorded by $\operatorname{lnGCI}$ indicated that the variables had a significant positive effect on the level of fraud, and that when lnGCI improved across time and between countries by 1 unit, the average effect on fraud led to an increase by 3.77 cases. The 
random-effects results shown in model 5 included only the regime type and the governance indexes without lnGCI and lnGDP, but the regime type being democratic was not significant though Gov1 and Gov3 were significant at $10 \%$ level. Thus, with only the governance indexes, a country being democratic or not was not significant in explaining the level of fraud reported by that country.

With the inclusion of the only regime type dummy as a control variable, the results of the fixed effects (as in model 6) showed that only Gov2 (consisting of VoA) was statistically significant at $10 \%$ level of significance. The coefficient of Gov2 ( $\beta=-.3957)$ indicated that the variable had significant negative effect on the level of fraud. Thus, for a given country, as voice and accountability improved over time by one unit, the number of fraud cases reduced by 0.3957 and as the VoA declined by one unit, the number of fraud cases rather increased by 0.3957. This finding indicates that as citizens get more involved in choosing those who govern them and the media gets more opportunity to hold leaders accountable, the level of fraud cases that are of international character reduces.

Table-8. Heteroskedastic-corrected regression results

\begin{tabular}{|c|c|c|c|c|c|c|c|c|}
\hline Variables & $\begin{array}{l}\text { Model 1 } \\
\text { Random } \\
\end{array}$ & $\begin{array}{l}\text { Model 2 } \\
\text { Fixed }\end{array}$ & $\begin{array}{l}\text { Model 3 } \\
\text { Random }\end{array}$ & $\begin{array}{l}\text { Model 4 } \\
\text { Random }\end{array}$ & $\begin{array}{l}\text { Model 5 } \\
\text { Random } \\
\end{array}$ & $\begin{array}{l}\text { Model } 6 \\
\text { Fixed }\end{array}$ & $\begin{array}{l}\text { Model } 7 \\
\text { Fixed }\end{array}$ & $\begin{array}{l}\text { Model } 8 \\
\text { Fixed }\end{array}$ \\
\hline Constant & $\begin{array}{l}1.5146^{* * * * *} \\
(0.1677)\end{array}$ & $\begin{array}{l}-1.8582 \\
(2.4986)\end{array}$ & $\begin{array}{l}1.5681^{* * * *} \\
(0.1814)\end{array}$ & $\begin{array}{l}-3.9751^{*} \\
(2.2000)\end{array}$ & $\begin{array}{l}1.5495^{* * * *} \\
(0.2183)\end{array}$ & $\begin{array}{l}-1.3829 \\
(2.5921)\end{array}$ & $\begin{array}{l}1.9422^{* * * *} \\
(0.0933)\end{array}$ & $\begin{array}{l}-0.9625 \\
(2.2419)\end{array}$ \\
\hline Gov 1 & $\begin{array}{l}0.0982^{*} * \\
(0.0478)\end{array}$ & $\begin{array}{l}0.1088 \\
(0.1318)\end{array}$ & $\begin{array}{l}\text { O.1395*** } \\
(0.0495)\end{array}$ & $\begin{array}{l}-0.0242 \\
(0.0887)\end{array}$ & $\begin{array}{l}0.1023^{*} \\
(0.0575)\end{array}$ & $\begin{array}{l}0.1478 \\
(0.1467)\end{array}$ & $\begin{array}{l}0.4891 \text { *** } \\
(0.1297)\end{array}$ & $\begin{array}{l}0.3922^{*} * \\
(0.1466)\end{array}$ \\
\hline Gov2 & $\begin{array}{l}-0.2810^{*} \\
(0.1567)\end{array}$ & $\begin{array}{l}-0.4652^{\text {*** }} \\
(0.2313)\end{array}$ & $\begin{array}{l}-0.2628^{*} \\
(0.1538)\end{array}$ & $\begin{array}{l}-0.0888 \\
(0.1546)\end{array}$ & $\begin{array}{l}-0.2564 \\
(0.1900)\end{array}$ & $\begin{array}{l}-0.3957^{*} \\
(0.2311)\end{array}$ & $\begin{array}{l}-0.3054 \\
(0.2194)\end{array}$ & $\begin{array}{l}-0.2878 \\
(0.2174)\end{array}$ \\
\hline Gov3 & $\begin{array}{l}-0.3427^{*} \\
(0.1903)\end{array}$ & $\begin{array}{l}0.1700 \\
(0.0132)\end{array}$ & $\begin{array}{l}-0.3091 \\
(0.2018)\end{array}$ & $\begin{array}{l}-0.2658 \\
(0.2188)\end{array}$ & $\begin{array}{l}-0.3548^{*} \\
(0.2036)\end{array}$ & $\begin{array}{l}-0.2126 \\
(0.2214)\end{array}$ & $\begin{array}{l}-0.3273 \\
(0.2102)\end{array}$ & $\begin{array}{l}-0.2803 \\
(0.2203)\end{array}$ \\
\hline $\operatorname{lnGCI}$ & & $\begin{array}{l}2.2836 \\
(1.6977)\end{array}$ & & $\begin{array}{l}3.7661^{* *} \\
(1.4908)\end{array}$ & & $\begin{array}{l}2.0808 \\
(1.7316)\end{array}$ & & $\begin{array}{l}1.9356 \\
(1.4939)\end{array}$ \\
\hline $\operatorname{lnGDP}$ & & & $\begin{array}{l}-0.0471 \\
(0.0764)\end{array}$ & $\begin{array}{l}-0.0484 \\
(0.0819)\end{array}$ & & & $\begin{array}{l}-0.0527 \\
(0.0795)\end{array}$ & $\begin{array}{l}-0.0619 \\
(0.0792)\end{array}$ \\
\hline Democratic & & & & & $\begin{array}{l}-0.0718 \\
(0.3458)\end{array}$ & $\begin{array}{l}-0.3604 \\
(0.2769)\end{array}$ & $\begin{array}{l}- \\
0.05301^{* * * *} \\
(0.1829)\end{array}$ & $\begin{array}{l}-0.4433^{*} * \\
(0.1940)\end{array}$ \\
\hline $\begin{array}{l}\text { R-Square: } \\
\text { Between } \\
\text { Overall } \\
\end{array}$ & $\begin{array}{l}9.9 \% \\
9.3 \% \\
\end{array}$ & $\begin{array}{l}9.15 \% \\
9.08 \% \\
\end{array}$ & $\begin{array}{l}7.3 \% \\
8.7 \% \\
\end{array}$ & $\begin{array}{l}17.8 \% \\
20.8 \%\end{array}$ & $\begin{array}{l}9.1 \% \\
8.7 \% \\
\end{array}$ & $\begin{array}{l}5.9 \% \\
6.2 \% \\
\end{array}$ & $\begin{array}{l}2.5 \% \\
2.7 \% \\
\end{array}$ & $\begin{array}{l}2.10 \% \\
3.73 \% \\
\end{array}$ \\
\hline Observations & 185 & 179 & 144 & 141 & 185 & 179 & 144 & 141 \\
\hline No. of groups & 37 & 36 & 37 & 35 & 37 & 36 & 37 & 35 \\
\hline F-test & & 4.92 & & & & 4.82 & 6.74 & 5.21 \\
\hline Wald chi-sq. & 14.74 & & 15.95 & 21.14 & 14.6 & & & \\
\hline $\begin{array}{l}\text { Prob }>\text { F } \\
\text { Prob }>\text { chi-sq. }\end{array}$ & 0.0021 & 0.0030 & 0.0031 & 0.0008 & 0.0056 & 0.0019 & 0.0002 & 0.0007 \\
\hline
\end{tabular}

However, variables without asterisk show that the coefficients are not significant up to $10 \%$ level of significance.

In model 7, the results of our fixed-effects regression, which included the two control variables and the governance indexes but without the competitiveness index showed that only Gov1 and regime type being democratic were significant at $5 \%$ level of significance in explaining fraud. Conversely, the fixed effects in model 8 , which include all the variables - governance indexes, competitiveness index and the two control variables - showed that only Gov 1 and the regime type being democratic respectively had significant positive and negative influence on the number of fraud cases reported. This implies that for a given country, as the governance indicators improved over time by one unit, the number of fraud cases rose by 0.3922 and as the indicators declined, the number of fraud cases also declined. Even though Gov2 and Gov3 had negative coefficients, they were insignificant. Economic growth and competitiveness were also insignificant. The coefficient of regime type being democratic $(\beta=-0.4433$; $\mathrm{p}-$ value $=0.029)$ implied that a country that was democratic recorded a decrease in the number of fraud cases than a country that was nondemocratic. A country that was democratic recorded a decrease in fraud cases by 0.4433 over time. Whereas the regime type being democratic was not statistically significant when ran with only the governance indexes, and even with competitiveness inclusive, it only became significant when we controlled for 
economic growth too. This situation was observed in models 5 to 8 , where regime type was not significant in models 5 and 6 (economic growth not included) but significant in models 7 and 8 (economic growth included).

\subsection{Discussion of Findings}

In all our eight models depicting different scenarios, governance indexes were found to be statistically significant in explaining the number of fraud cases recorded by countries over time, except in model 4 . When we do away with the control variables, economic growth and regime type as well as the competitiveness index and include only the governance indexes in our model, all the governance indexes were statistically significant. While Gov 1 had a significant positive outcome, Gov2 and Gov3 had significant negative outcomes. The results depict that in all the five instances that Gov1 was significant (models 1, 3, 5, 7 and 8), the direction was positive, which was unexpected since we anticipated improved governance indicators to have a negative relationship with the number of fraud cases recorded. Nonetheless, the four scenarios that Gov2 was statistically significant (models 1, 2, 3 and 6), it recorded a negative sign as expected just as Gov3, which also showed a significant negative sign in two instances (models 1 and 5). Thus, on average, countries that showed improved political stability/absence of violence and enhanced voice and accountability ranking reported a decrease in fraud cases. However, on average, countries that ranked higher in terms of control of corruption, government effectiveness, regulatory quality and rule of law recorded greater number of fraud cases over the years. These outcomes confirm the findings of Sadaf et al. (2018) who observed that political stability had significant negative influence on the number of frauds while government effectiveness had a significant positive influence on the number of frauds.

In all the four models that competitiveness index appeared (models 2, 4, 6 and 8), it was positive but only statistically significant in model 4, where no governance index was significant. Thus, competitiveness index of countries had a positive impact on the number of accounting fraud cases reported. This situation was also not expected as the global competitiveness of a country was anticipated to have a negative effect on the level of fraud. Thus, while national competitiveness index rose, stakeholders become more motivated to organize their affairs such that they are able to get processes and institutions working to inure to their benefits that led to increase in international accounting fraud. The correlational analysis, however, indicated that with the exception of voice and accountability, the competitiveness index showed a significant positive correlation with all other explanatory variables. This confirms the works of Podobnik et al. (2012) and Ulman (2013).

The inclusion of our control variables also presented some variation in our findings. GDP appeared in four models (3, 4, 7 and 8) and was negative in all cases, which was expected except that it was insignificant. The negative sign would have implied that as an economy grew higher, the level of fraud cases reduced except that it was not a robust determinant of number of fraud cases reported. However, regime type appeared in four models (5, 6, 7 and 8) and was negative in all cases but showed a significant negative relationship with fraud in two models (7 and 8) out of the four. Thus, regime type being democratic showed to be a robust determinant of level of international fraud, which implied that countries that were democratic saw a reduction in the average number of fraud cases reported. This corroborates the earlier finding with respect to voice and accountability, which also showed a negative influence on fraud as democratic nations generally tend to score higher in terms of voice and accountability.

\section{CONCLUSION AND POLICY IMPLICATIONS}

Understanding the key elements of fraud is the most fundamental issue to consider in any effort to deal with fraud. Due to the complexity of accounting fraud in varied environmental settings, there is the need to tackle the phenomenon from international perspectives to provide fundamental theories that will consider the differences in countries. From an institutional perspective, this paper contributes to literature on fraud and governance through an analysis of data from 37 OBOR countries. From the findings made, we can conclude that, apart from rule of law, 
all the other governance indicators only affect the level of fraud in one way or the other but their effect is not significant. However, the more effective and predictable the judiciary becomes and contracts become enforceable, the more fraud cases continue to rise. This raises questions on the role played by judicial systems in protecting contracts. Perpetrators of fraud apparently organize their crimes such that they become somehow legitimate before the law courts and other law enforcement agencies. Our results also showed that the competitiveness of countries exhibit a positive effect on the level of fraud cases reported, an indication that while an economy becomes globally competitive, it also becomes fertile grounds for fraud to thrive. The findings of this study suggest that motivation for the commission of fraud goes beyond the stipulations in the fraud triangle and diamond theories. Thus, societal influences as indicated by Cieslewicz (2010) in this case institutional factors, competitiveness and governance models, must be considered as critical elements to understand and explain fraud. Our results also revealed that governance regime type significantly affects fraud, and that countries that were democratic recorded a lower number of fraud that those that were not.

The evidences revealed by the outcomes of this study suggest that the quality of governance remains an integral aspect of any anti-fraud effort across and within individual countries. Generally, anti-corruption campaign remains a topmost priority in the development agenda of the People's Republic of China. An initiative to get other countries on board towards global cooperation for world development should, therefore, be made to thrive on antifraud efforts by connected countries. This study suggests for an integrated approach to dealing with fraud, which considers various governance dimensions. Governments are urged to empower citizens, especially the media to be able to have voice to hold those in positions of trust accountable through appropriate channels such as the passing of whistle-blowing legislation, among others.

Despite having organized the study to ensure that the main findings remain robust given the alternative specifications made, caution must be taken in generalizing since the focus of the study was on only OBOR countries. Again, while other corporate-specific governance determinants may affect reported cases of fraud, our study did not include such variables due to data inaccessibility. Thus, the validity of our findings is limited by the non-inclusion of the corporate governance variables in our model. The limitations stated, however, do not invalidate the outcomes of this study as we have been able to establish that a relationship exists between governance and fraud, which adds to literature. Nonetheless, we are of the view that a carefully constructed database on fraud occurrences other than those reported by some experts based on their perception and experience, will give a broader view of fraud cases of nations to be able to relate to general governance dimensions. We suggest that further studies be conducted in the future using an expanded sample size of countries that have not signed to the BRI from international accounting fraud perspective considering other comprehensive fraud and governance measures.

Funding: This study received no specific financial support.

Competing Interests: The authors declare that they have no competing interests.

Acknowledgement: All authors contributed equally to the conception and design of the study.

\section{REFERENCES}

Abdullahi, R., \& Mansor, N. (2015a). Concomitant debacle of fraud incidences in the Nigerian public sector: Understanding the power of fraud triangle theory. International Journal of Academic Research in Business and Social Sciences, 5(5), 312-326.

ACFE. (2016). Report to the nations on occupational fraud and abuse. Austin, TX, USA: ACFE.

ACFE. (2018). Report to the nations on occupational fraud and abuse. Austin, TX, USA: ACFE.

Adams, F., Gangnes, B., \& Shachmurove, Y. (2006). Why is China so competitive? Measuring and explaining China's competitiveness. World Economy, 29, 95-122.Available at: https://doi.org/10.1111/j.1467-9701.2006.00773.x.

Albrecht, W. S., Albrecht, C., \& Albrecht, C. C. (2008). Current trends in fraud and its detection. Information Security Journal: $A$ Global Perspective, 17(1), 2-12. 
Albrecht, C. O., \& Albrecht, C. C. (2009). International ethics, fraud, and corruption: A cross-cultural perspective. Cross Cultural Management: An International Journal, 16(3).Available at: https://doi.org/10.1 108/com.2009.13616caa.001

Amar, B. A., \& Hamdi, T. H. (2012). Global competitiveness and economic growth: Empirical verification for African countries. International Journal of Economics and Finance, 4(6), 125-131.

Asgharian, H., Liu, L., \& Lundtofte, F. (2014). Institutional quality, trust and stock market participation: learning to forget. KNUT Wicksell Working Paper, 2, Lund University.

Barro, R. (1991). Economic growth in a cross-section of countries. Quarterly Journal of Economics, 106(2), 407-443.Available at: https://doi.org/10.2307/2937943.

Berger, T., \& Bristow, G. (2009). Competitiveness and the benchmarking of nationa - a critical reflection. International Advances in Economic Research, 15(4), 379-392.Available at: https://doi.org/10.1007/s 11294-009-9231-x.

Bhawsar, P., \& Chattopadhyay, U. (2015). Competitiveness: Review, reflections and directions. Global Business Revierw, 16(4), 665679.Available at: https://10.1177/0972150915581115.

Bishop, C. C., Hermanson, D. R., \& Riley, R. A. (2017). Collusive Fraud: Leader, incident, and organizational characteristics. Journal of Forensic Accounting Research, 2(1), 49-70.Available at: https://doi.org/10.2308/jfar-5 1826.

Chin, H., \& He, W. (2016). The belt and road initiative: 65 countries and beyond. Hong Kong: Fund Business Intelligence Center.

Chukwunedu, O. S., Okafor, G. O., \& Oraka, A. O. (2012). Management fraud and global competitiveness of sub-Saharan economies - evidence from the Nigerian banking industry. Available at SSRN: https://ssrn.com/abstract=2192860 or http://dx.doi.org/10.2139/ssrn.2192860.

Cieslewicz, J. K. (2010). The fraud square: societal influences on the risk of fraud. Paper presented at the Paper presented at 2010 American Accounting Association Annual Meeting, 31 July - 4 August, San Francisco.

Cieslewicz, J. K. (2012). The fraud model in international contexts: A call to include societal-level influences in the model. Journal of Forensic Investigation and Accounting, 4(1), $214-254$.

Cressey, D. R. (1950). The criminal violation of financial trust. American Sociological Review, 15(6), 738-743.Available at: 10. $2307 / 2086606$.

Cressey, D. R. (1953). Other people's money. Montclair, NJ: Patterson Smith.

Crumbley, D. L., Heitger, L. E., \& Smith, G. S. (2015). Forensic and investigative accounting (8th ed.). Chicago: CCH Inc.

El-Namaki, M. S. S. (2002). An analysis of China's competitiveness between 1995 and 1999. Competitiveness Reviere, 12, 66-75.

Farole, T., Rodríguez-Pose, A., \& Storper, M. (2011). Cohesion policy in the European Union: growth, geography, institutions. Journal of Common Market Studies, 49(5), 1089-1111.Available at: 10.1111/j.1468-5965.2010.02161.x

Fleming, A. S., Hermanson, D. R., Kranacher, M., \& Riley, R. A. J. (2016). Financial reporting fraud: Public and private companies. Journal of Forensic Accounting Research, 1(1), 27-41.Available at: https://doi.org/10.2308/iace-50131.

Free, C. (2015). Looking through the fraud triangle: A review and call for new directions. Meditari Accounting Research, 23, 175196.

Goulas, E., \& Zervoyianni, A. (2015). Economic growth and crime: Is there an asymmetric relationship? Economic Modelling, 49(1), 286-295.

Hafeez, M., Chunhui, Y., Strohmaier, D., Ahmed, M., \& Jie, L. (2018). Does finance affect environmental degradation: Evidence from One Belt and One Road Initiative region? Environmental Science and Pollution Research, 25, 1-14.Available at: https://doi.org/10.1007/s11356-018-1317-7.

Haq, R., \& Zia, U. (2009). Does governance contribute to pro-poor growth? Evidence from Pakistan. PIDE Working Papers No. 52, Institute of Development Economic, Islamabad.

Harrison, L. E., \& Huntington, S. P. (2000). Culture matters: How values shape human progress New York: Basic Books.

Hausman, J. A. (1978). Specification tests in econometrics. Economic Modelling, 46, 1251-1271.

Hillman, A. J., \& Wan, W. P. (2005). The determinants of MNE subsidiaries' political strategies: Evidence of institutional duality. Journal of International Business Studies, 36(3), 322-340.Available at: https://doi.org/10.1057/palgrave.jibs.8400137. 
Huang, Z. (2017). One belt, one road: Your guide to understanding OBOR, China's new silk road plan. Quartz.

Huther, J., \& Shah, A. (1996). A simple measure of good governance. Washington, DC: Operations Evaluation Department, World Bank.

IFAC. (2013). International Standard on Auditing (ISA) 240, The auditor's responsibilities relating to fraud in an audit of financial statements. Handbook of International Quality Control, Auditing Review, Other Assurance, and Related Services Pronouncements. New York: IFAC.

Kaufmann, D., Kraay, A., \& Mastruzzi, M. (2003). Governance matters III: Governance indicators for 1996-2002. Policy Research Working Paper No. 3 106, The World Bank, Washington, DC.

Kaufmann, D., Kraay, A., \& Mastruzzi, M. (2010). The worldwide governance indicators: Methodology and analytical issues. Policy Research Working Paper Series 5430; The World Bank: Washington, DC, USA.

Kaufmann, D., Kraay, A., \& Mastruzzi, M. (2011). The worldwide governance indicators: Methodology and analytical issues. Hague Journal on the Rule of Law, 3, 220-246.Available at: https:// 10.1017/S1876404511200046.

Kaufmann, D., Kraay, A., \& Zoido-Lobatón, P. (1999). Aggregating governance indicators. Policy Research Working Paper No. 2195, The World Bank, Washington, DC.

Knack, S., \& Keefer, P. (1995). Institutions and economic performance: Cross-country tests using alternative institutional measures. Economics \& Politics, 7(3), 207-227.Available at: https://doi.org/10.1111/j.1468-0343.1995.tbo0111.x.

Kordalska, A., \& Olczyk, M. (2015). Global competitive and economic growth: a one-way or two-way relationship? Institute of Economic Research Working Papers No. 63/2015.

Korez-Vide, R., \& Tominc, P. (2016). Competitiveness, entrepreneurship and economic growth. In Competitiveness of CEE Economies and Businesses (pp. 25-44). Cham: Springer.

Královičová, M., \& Zatko, M. (2016). One belt one road initiative in Central Asia: implications for competitiveness of Russian economy. Working Paper No. 2016/9, Maastricht School of Management.

Krambia-Kapardis, M. (2016). Financial crisis, fraud, and corruption. In Corporate Fraud and Corruption (pp. 5-38). Palgrave Macmillan US: New York, NY, USA.

Kranacher., M. J., Riley, J. R. A., \& Wells, J. T. (2011). Forensic accounting and fraud examination. New York: John Wiley \& Sons.

Kuwornu, J. K. M. (2012). Effect of macroeconomic variables on the Ghanaian stock market returns: A co-integration analysis. Agris on-line Papers in Economics and Informatics, 4(2), 1-12.

Lall, S. (2001). Competitiveness indices and developing countries: An economic evaluation of the global competitiveness report. World Development, 29(9), 1501-1525.Available at: https://10.1016/s0305-750x(01)0005 1-1.

Liu, Y., Xu, C., \& Zhang, Y. (2010). An analysis on the international competitiveness of China's traditional medicine industry based on the SWOT model. International Journal of Business and Management, 5(7), 225-229.Available at: https://doi.org/10.5539/ijbm.v5n7p225.

Manurung, D. T. H., \& Hadian, N. (2013). Detection fraud of financial statement with fraud triangle. Paper presented at the Proceedings of the 23rd International Business Research Conference, 18-20. Marriott Hotel, Melbourne, Australia.

Máté, D., Sadaf, R., Oláh, J., Popp, J., \& Szücs, E. (2019). The effects of accountability, governance capital, and legal origin on reported frauds. Technological and Economic Development of Economy, 25(6), 1213-1231.Available at: https://doi.org/10.3846/tede.2019.10717.

Morales, J., Gendron, Y., \& Gue' nin-Paracini, H. (2014). The construction of the risky individual and vigilant organization: A genealogy of the fraud triangle. American College of Cardiology, 39(3), 170-194.Available at: https://doi.org/10.1016/j.aos.2014.01.006.

North, D. C. (1990). Institutions, ideology and economic performance. Cato Journal, 11, 477-496.

North, D. C. (1994). Economic performance through time. The American Economic Review, 84(3), 359-368.

Park, H. M. (2011). Practical guides to panel data modeling: a step-by-step analysis using stata. Public Management and Policy Analysis Program, Graduate School of International Relations, International University of Japan, 12, 1-52. 
Podobnik, B., Horvatić, D., Kenett, D. Y., \& Stanley, H. E. (2012). The competitiveness versus the wealth of a country. Scientific Reports, 2(1), 1-7.Available at: https://doi.org/10.1038/srep00678.

Ramamoorti, S., \& Olson, W. (2007). Fraud: The human factor. Financial Executive, 23(6), 53-55.

Ramamoorti, S., Morrison, D., \& Koletar, J. W. (2009). Bringing freud to fraud: Understanding the state-of-mind of the C-level suite/white-collar offender through A-B-C analysis. Accounting Faculty Publications, 71. Institute for Fraud Prevention, West Virginia University.

Ranjan, V., \& Agrawal, G. (2011). FDI inflow determinants in BRIC countries: A panel data analysis. International Business Research, 4(4), 255-263.Available at: https://doi.org/10.5539/ibr.v4n4p255.

Reurink, A. (2016). Financial fraud: A literature review. MPIfG Discussion Paper No. 16/5. Cologne: Max Planck Institute for the Study of Societies.

Rezaee, Z., \& Wang, J. (2018). Relevance of big data to forensic accounting practice and education. Managerial Auditing Journal, 34(1), 268-288.Available at: https://doi.org/10.1108/MAJ-08-2017-1633.

Rutherford, M. (2001). Institutional economics: Then and now. Journal of Economic Perspectives, 15(3), 173-194.Available at: https://doi.org/10.1257/jep.15.3.173.

Sadaf, R., Oláh, J., Popp, J., \& Máté, D. (2018). An investigation of the influence of the worldwide governance and competitiveness on accounting fraud cases: A cross-country perspective. Sustainability, 10(3), 1-11.Available at: https://doi.org/10.3390/su10030588.

Schwab, K. (2018). The global competitiveness report 2017-2018. Geneva: The World Economic Forum.

Scott, W. R. (2001). Institutions and organizations (2nd ed.). Thousand Oaks, CA: Sage.

Shao, J., Ivanov, P. C., Podobnik, B., \& Stanley, H. E. (2007). Quantitative relations between corruption and economic factors. The European Physical Journal B, 56(2), 157-166.Available at: https://doi.org/10.1140/epjb/e2007-00098-2.

Shapiro, S. S., \& Wilk, M. B. (1965). An analysis of variance test for normality (complete samples). Biometrika, 52(3/4), 591611.Available at: https://doi.org/10.2307/2333709.

Shi, Y., Magnan, M., \& Kim, J.-B. (2012). Do countries matter for voluntary disclosure? Evidence from cross-listed firms in the US. Journal of International Business Studies, 43(2), 143-165.Available at: https://doi.org/10.1057/jibs.2011.38.

Siyakiya, P. (2017). The impact of institutional quality on economic performance: An empirical study of European union 28 and prospective member countries. World Journal of Applied Economics, 3(2), 3-24.Available at: https://doi.org/10.22440/wjae.3.2.1.

Suchman, M. C. (1995). Managing legitimacy: Strategic and institutional approaches. Academy of Management Review, 20(3), 571610.Available at: https://doi.org/10.5465/amr.1995.9508080331.

Sutherland, E. H. (1938). The professional thief (pp. xiii, 257). Chicago: University of Chicago Press.

Ulman, S.-R. (2013). Corruption and national competitiveness in different stages of country development. Procedia Economics and Finance, 6, 150-160.Available at: https://doi.org/10.1016/s2212-5671(13)00127-5.

Wolfe, D. T., \& Hermanson, D. R. (2004). The fraud diamond: Considering the four elements of fraud. CPA Journal, 74, 38-42.

World Bank. (2019). World development indicators. Washington DC: World Bank.

World Economic Forum. (2019). The global competitiveness report (2010 - 2018). Geneva.

World Governance Indicators (WGI). (2018). Retrieved from: https://data.worldbank.org/data-catalog/worldwide-governanceindicators.

Yang, H., Ji, C., Nie, Y., \& Yinxing, H. (2013). China's wood furniture manufacturing industry: Industrial cluster and export competitiveness. Forest Products Journal, 62, 214-221.

Zhao, Z., \& Zhang, K. H. (2007). China's industrial competitiveness in the world. Chinese Economy, 40(6), 6-23.Available at: https://doi.org/10.2753/ces1097-1475400601.

Zhuang, J., de Dios, E., \& Martin, A. L. (2010). Governance and institutional quality and the links with economic growth and income inequality: with special reference to developing Asia. Asian Development Bank (ADB) Working Paper No. 193, Manila, Philippines. Retrieved from: http://hdl.handle.net/11540/1537. 


\section{APPENDIX}

\begin{tabular}{|c|c|c|c|c|c|}
\hline Country & Region & Country & Region & Country & Region \\
\hline 1. China & \multirow[t]{2}{*}{ East Asia } & 27. Bahrain & \multirow{15}{*}{$\begin{array}{l}\text { Middle East \& } \\
\text { North Africa }\end{array}$} & 53. Latvia & \multirow{13}{*}{ Europe } \\
\hline 2. Mongolia & & 28. Egypt & & 54. Lithuania & \\
\hline 3. Brunei & \multirow{11}{*}{$\begin{array}{l}\text { South-East } \\
\text { Asia }\end{array}$} & 29. Iran & & 55. Macedonia & \\
\hline 4. Cambodia & & 30. Iraq & & 56. Moldova & \\
\hline 5. Indonesia & & 31. Israel & & 57. Montenegro & \\
\hline 6. Laos & & 32. Jordan & & 58. Poland & \\
\hline 7. Malaysia & & 33. Kuwait & & 59. Romania & \\
\hline 8. Myanmar & & 34. Lebanon & & 60. Russia & \\
\hline 9. Philippines & & 35. Oman & & 61. Serbia & \\
\hline 10. Singapore & & 36. Palestine & & 62. Slovakia & \\
\hline 11. Timor-Leste & & 37. Qatar & & 63. Slovenia & \\
\hline 12. Thailand & & 38. Saudi Arabia & & 64. Turkey & \\
\hline 13. Vietnam & & 39. Syria & & 65. Ukraine & \\
\hline 14. Afghanistan & \multirow{8}{*}{ South Asia } & 40. UA Emirates & & & \\
\hline 15. Bangladesh & & 41. Yemen & & & \\
\hline 16. Bhutan & & 42. Albania & \multirow{11}{*}{ Europe } & & \\
\hline 17. India & & 43. Armenia & & & \\
\hline 18. Maldives & & 44. Azerbaijan & & & \\
\hline 19. Nepal & & 45. Belarus & & & \\
\hline 20. Pakistan & & 46. Bosnia & & & \\
\hline 21. Sri Lanka & & 47. Bulgaria & & & \\
\hline 22. Kazakhstan & \multirow{5}{*}{ Central Asia } & 48. Czech & & & \\
\hline 23. Kyrgyzstan & & 49. Croatia & & & \\
\hline 24. Tajikistan & & 50. Estonia & & & \\
\hline 25. Turkmenistan & & 51. Georgia & & & \\
\hline 26. Uzbekistan & & 52. Hungary & & & \\
\hline
\end{tabular}

....... Maritime Silk Road initiative

........ Silk Road Economic Belt

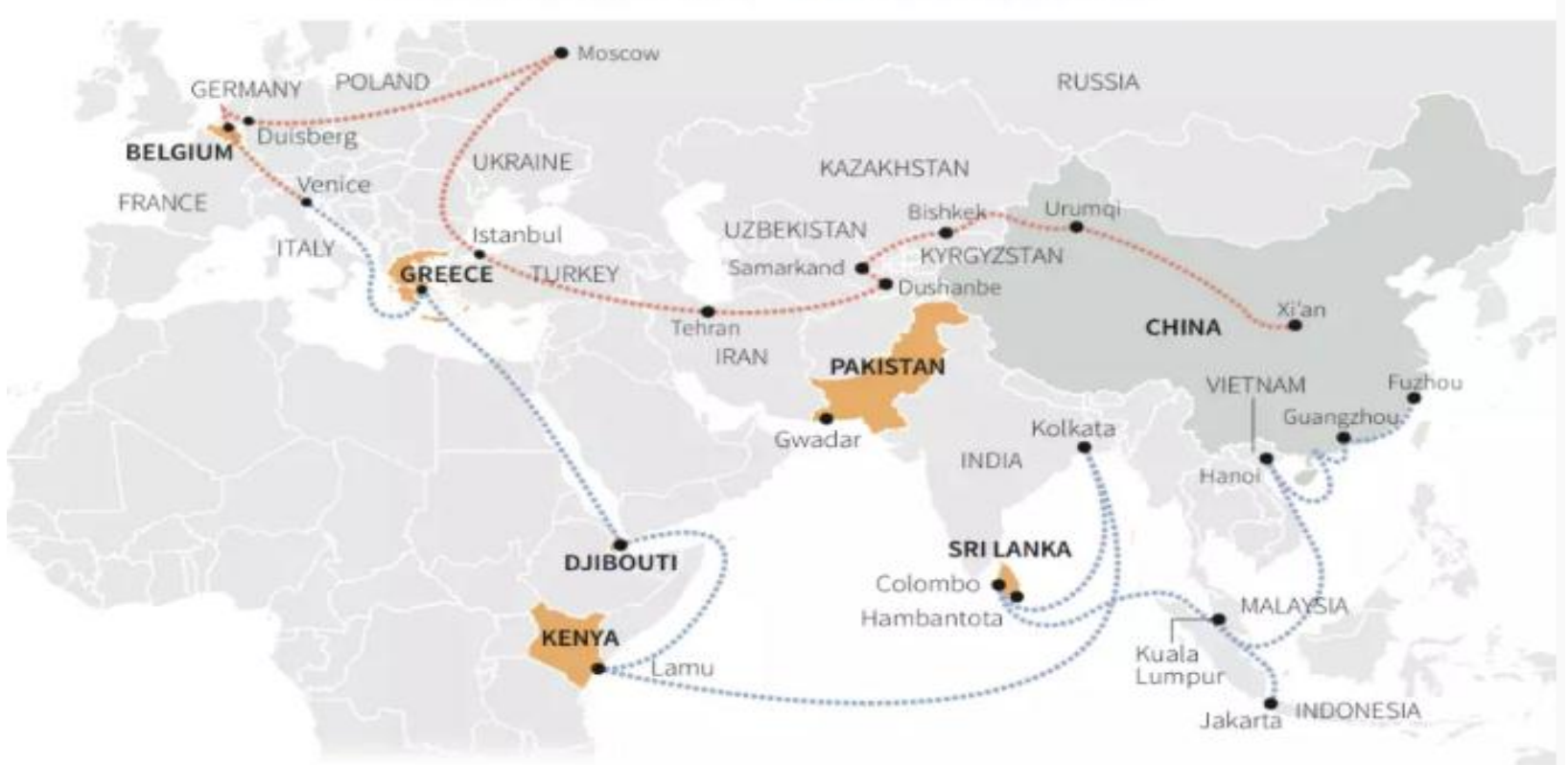

Source: Huang (2017).

Appendix-2. The silk road economic belt and maritime silk road initiative.

Views and opinions expressed in this article are the views and opinions of the author(s), The Economics and Finance Letters shall not be responsible or answerable for any loss, damage or liability etc. caused in relation to/arising out of the use of the content. 